Bogustawa Dorota Golębniak

ORCID: 0000-0002-6163-5208

Dolnośląska Szkoła Wyższa

dorota.golebniak@dsw.edu.pl

\title{
Konstruktywistyczna edukacja do \\ konstruktywistycznego nauczania. Redefinicja relacji \\ teorii i praktyki w akademickim kształceniu nauczycieli
}

\begin{abstract}
Summary
Constructive education for constructive teaching. Redefining the relationship between theory and practice in academic teacher education

In this article, I discuss adult learning models and their implications in the field of academic didactics addressed to teacher candidates, which seem adequate to thinking about teaching (learning) in school inspired by constructivist-interpretative paradigms (Klus-Stańska 2018). Referring to David Guile's (2005b) typology of approaches to professional education, which takes into account the criterion of the adopted theories of learning (a monological approach based on cognitivism, a dialogical/participatory approach, rooted in the model of cognition situated in context, and a trialogical approach corresponding to the theory of activity along with social constructivism), I compare the implications of the differentiated re/defining of the theory and practice relations in the programmes of the pedagogical component of studies constructed in accordance with the identified approaches.
\end{abstract}

Keywords: constructivism, knowledge situated in context, cultural-historical theory of activity, monological, dialogical and trialogical approach in education to teaching, teaching by projects, research in action, formative interventions

Słowa kluczowe: konstruktywizm, wiedza usytuowana w kontekście, kulturowo-historyczna teoria działalności, monologiczne, dialogiczne i trialogiczne podejście w edukacji do nauczania, uczenie projektami, badania w działaniu, interwencje formatywne.

\section{Wprowadzenie}

„Konstruktywistyczna szkoła” wymaga „konstruktywistycznego” w szerokim znaczeniu, zbliżonym do rozumienia w kontekście anglosaskim terminu curriculum, programu akademickiej edukacji nauczycieli. Wyzwanie to nabiera obecnie - w sytuacji wymuszonej ieduakcji (Czerepaniak-Walczak 2020) - dramatycznego wręcz charakteru. Nawarstwienie w tym obszarze różnorakich problemów, związanych zarówno z dominacją modelu paralelnego w akademickiej edukacji nauczycieli przedmiotów szkolnych (sytuowanie tzw. przygotowania pedagogicznego niejako na marginesie studiów kierunkowych, bez ściślejszego 
powiązania z programem studiów kierunkowych), jak i z częściowym „wypchnięciem” modelu konsekutywnego (przyjmującego postać studiów nauczycielskich budowanych na studiach kierunkowych) poza uniwersytety ${ }^{1}$, powoduje, że „tu i teraz” zależeć nam powinno nie tyle na formalnej rekonstrukcji systemu przygotowania do nauczania, ile na głębszej, niepozorowanej zmianie programowej. Podejmowane od czasu do czasu „reformy” w postaci ogłaszania kolejnych wersji standardów kształcenia nauczycieli², niewsparte zmianą podstaw filozoficzno-psychologicznych i wynikających z nich strategii pracy edukacyjnej z kandydatami i funkcjonującymi już w zawodzie nauczycielami, nie wpływają znacząco na zmianę kultury szkoły via edukacja nauczycieli. Utwierdzają w tym nie tylko obiegowe opinie, ale i różne rozpoznania empiryczne, oparte na ilościowych i jakościowych danych (Dudzikowa, Knasiecka-Flabierska 2013; Legierska 2013; Dudzikowa, Jaskulska 2016; Klus-Stańska, Nowicka 2019). Wpisanie w dokumentacji terminów wywodzących się z najnowszych teorii rozwoju i koncepcji uczenia się (z konektywizmem włącznie) i treści sugerujących funkcjonowanie nauczyciela w roli badacza, podobnie jak określanie liczby godzin, które należy przeznaczyć na realizację poszczególnych bloków zajęć teoretycznych i na praktyki w szkołach, nie są w stanie zmienić ,sceny” ani reguł gry (dominującego modus operandi) edukatorów nauczycieli (Atroszko 2020).

Współautorska diagnoza akademickiego modelu kształcenia nauczycieli w Polsce, oparta na szerokiej próbie badawczej, ujawniła, jak mozaikowość programów, ich podporządkowanie biurokratycznie „czytanym” zapisom państwowych standardów kształcenia nauczycieli utrudniają zmianę status quo w kierunku przygotowania do konstruktywistycznego nauczania (Gołębniak, Krzychała 2015). Wydaje się, że tylko odrzucenie modelu przekazu treści nauczania wraz z towarzyszącą mu konwencją praktyk, zachęcającą jedynie z założenia do wiązania teorii w praktyce, bo ograniczającą de facto jej efekty do (a)refleksyjnego modelowania zastanych wzorów „dobrego nauczania”, otwiera przestrzeń do zmiany na poziomie epistemologicznym. Kluczowe wydaje się wypracowywanie takiego podejścia do kreowania czy opracowywania programu (zob. Gołębniak 2019: 875-898), które adekwatnie do przesunięć konceptualnych w szkolnym nauczaniu ${ }^{3}$ zredefiniuje relację teorii i praktyki w kształceniu profesjonalnym nauczycieli.

Pytanie, które stawiam w tekście, dotyczy zatem tego, jak po przesunięciu konceptualnym i zwrocie metodologicznym w pedeutologii może być redefiniowana relacja między

\footnotetext{
1 Mam tu na uwadze nie tylko brak akredytacji studiów podyplomowych prowadzących do uzyskania kwalifikacji do nauczania, ale i różnorakie formy omijania formalnych zapisów dotyczących wiązania tego typu oferty kształcenia z potencjałem akademickim instytucji.

2 Zob. Rozporządzenie Ministra Nauki i Szkolnictwa Wyższego z dnia 25 lipca 2019 r. w sprawie standardu kształcenia przygotowującego do wykonywania zawodu nauczyciela, Dz. U. z 2019 r., poz. 1450, ze zm., http://isap.sejm.gov.pl/isap.nsf/DocDetails.xsp?id=WDU20190001450, 31.11.2020.

3 Przesunięcia konceptualne, stanowiące przełożenie założeń paradygmatycznych na strategie/zadania dydaktyczne można sformułować dość lapidarnie jako przejście/przechodzenie od nabywania wiedzy do jej konstruowania, od akcentowania „produktów” do skupienia na procesie uczenia się i budowania metawiedzy, od pracy frontalnej adresowanej do zbioru indywiduów do osadzania uczenia się w kontekście społeczno-kulturowym.
} 
teorią a praktyką w nie-scjentystycznych podejściach do pracy edukacyjnej ze studentami i praktykami-nauczycielami. Wraz z upowszechnieniem szeroko ujmowanej perspektywy konstruktywistycznej w nauczaniu (Gołębniak 2005) okazuje się, że aplikacje skupione na rozumieniu istoty „konstruowania” wiedzy prowadzą do różnic w sposobach integrowania teorii i praktyki. Biorąc zatem pod uwagę wewnętrzne zróżnicowanie paradygmatów konstruktywistyczno-interpretacyjnych (Klus-Stańska 2018) i uwzględniając kryterium „sprawdzonej” już (choć wyspowej) obecności kognitywizmu, poznania usytuowanego w kontekście i kulturowo-historycznej teorii działalności ${ }^{4}$ w przestrzeni edukacji nauczycieli, zajęłam się interesującą nas tu kwestią w ramach typologii Davida Guile'a (2005b). Wyróżnione przez niego podejścia: monologiczne, dialogiczne i trialogiczne, spełniając kanon dydaktyczny „konstruktywizmu w działaniu”, adekwatnie do rozumienia istoty uczenia się, różnią się zasadami przyjmowanymi w pokonywaniu klasycznych opozycji: teoria versus praktyka, wiedza versus działanie, nauczanie versus uczenie się.

\section{Kognitywizm i podejście monologiczne}

Kognitywizm w znaczeniu stanowiska teoretycznego w programach edukacji nauczycieli do konstruktywistycznego nauczania obejmuje szeroki zestaw teorii i koncepcji konstruowanych w różnych dyscyplinach nauki. Teorie uczenia się fundowane na gruncie eksperymentalnej psychologii poznania łączą w zajmowaniu się tym, co „ludzie mają w głowach", podobnie jak behawioryzm, w stosunku do którego pozostają w opozycji, takie intelektualne tradycje, jak: pozytywizm, racjonalizm i humanizm. Rozwój tego nurtu psychologii, zwanego od opublikowania przez jednego z najbardziej znaczących przedstawicieli, Ulricha Neissera, psychologią kognitywną (1967), pozostaje od początku pod wpływem lingwistyki (najpierw Noama Chomsky'ego (1968), a następnie George'a Lakoffa i Marka Johnsona (2020), a ostatnio Andy'ego Clarka (2008)) oraz filozofii umysłu (od Johna Rogersa Searle'a (1967) jednego z twórców tzw. komputacyjnych teorii umysłu - po teorie modularne umysłu autorstwa Jerry'ego A. Fodora (2011) $)$. Począwszy od

${ }^{4}$ Oczywiście nie jest to pełna reprezentacja modeli uczenia się dorosłych. Jedna $\mathrm{z}$ typologii, autorstwa Karin Tusting i Davida Bartona (2003) dzieli je na dwie części - wywodzące się z psychologii, do których oprócz już wskazanych zalicza także: behawioryzm, teorie rozwojowe, wiedzę o mózgu oraz modele wywodzące się z wprost z edukacji dorosłych, takie jak: krytyki andragogiczne, uczenie się samodyrektywne, nieformalne uczenie się, modele reflektywne i eksperymentalne czy transformatywne uczenie się (Tusting, Barton 2003).

5 Zwolennicy modularnej koncepcji umysłu ludzkiego traktują umysł człowieka w kategoriach specjalistycznych podsystemów kognitywnych, czyli tzw. modułów mentalnych i niezależnych procesorów, które rozwijają się niejednorodnie, działając w zgodzie z ,wyznaczonymi” im zasadami (przy określonych ograniczeniach). Mają one odrębną strukturę i zadania, a z aktem poznawczym mamy do czynienia w trakcie interakcji zachodzącej między nimi na płaszczyźnie input-output różnych modułów, a więc w sposób niczego niezmieniający w ich strukturze. Zdaniem niektórych badaczy modularna teoria umysłu ma duże znaczenie w dalszym rozwoju m.in. glottodydaktyki (por. Sadownik 2012). 
lat $80 . \mathrm{XX}$ w. przedstawiciele kolejnych generacji kognitywizmu poznawczego przypisują językowi coraz większą rolę w procesie poznania. Oprócz nawiązywania do filozofii umysłu J.R. Searle'a czy odnoszenia się do filozofii języka Ludwiga Wittgensteina, w najnowszych pracach kognitywistów (zarówno o psychologicznej, jak i antropologicznej czy lingwistycznej proweniencji) można zauważyć ideę poszerzenia funkcji języka nie tylko o wymiary interakcyjne, ale i kolaboratywne. Nauczyciele i edukatorzy są w ten sposób zachęcani do poszerzania facylitacji procesów przetwarzania struktur poznawczych w umysłach pojedynczych osób. Koncepcje kulturowych źródeł ludzkiego poznania (Tomasello 2002) czy „współdzielenia intencjonalności” działań (Tomasello 2015), czy rozproszonego poznania, w tym stosowania metodologii jakościowej w badaniu interakcji człowiek-komputer (Hutchins 1995), otwierają - jak się dość powszechnie wydaje nowy rozdział dydaktyki opartej na kognitywistycznej wiedzy o procesach mentalnych.

Ostatnio nowy ton do tego podejścia wprowadzają przedstawiciele neuronauk. Prowadzone przez nich badania nad umysłem jako funkcją mózgu nie tylko potwierdzają, że uczenie się wymaga aktywnego zaangażowania podmiotów, ale wskazując też na mentalną złożoność tej aktywności, dokonują - poprzez dostarczanie neurobiologicznych uzasadnień (zob. np. Spitzer 2007; Damásio 2011) - przesunięcia zainteresowań dydaktyki szkolnej w kierunku poszukiwań w miarę uniwersalnych technik facylitacji procesów uzyskiwania przez osoby uczące się osobistego rozumienia, czego i jak się uczą (zob. np. Dylak 2013; Siemieniecki 2013; Żylińska 2013).

Przyjmowanie w pedagogicznym, a w zasadzie w dydaktycznym, komponencie studiów profesjonalnych kandydatów na nauczycieli tego stanowiska w zakresie uczenia się stawia autorów programu wobec wyzwania projektowania takich form aktywności (łączących myślenie i działanie), które mogą prowadzić do względnie trwałych zmian w wiedzy. Nadawanie znaczeń nowo pojawiającym się w polu eksploracji faktom i procesom, włączanie ich do dotychczasowego zasobu - chodzi nie tyle o przyrost, ile o zmianę jakościową w repertuarze wiedzy i umiejętności - muszą skłaniać ku zastąpieniu strategii „kolekcji” (przedmiotów i występujących w nich teorii i koncepcji) strategią „integracji” treści i metod z wybranych subdyscyplin pedagogiki, psychologii, socjologii, studiów z zakresu polityki oświatowej. Indywidualne bądź zespołowe rozwiązywanie problemów uwzględniających potrzeby otoczenia to dominująca strategia dydaktyczna.

Model, zgodnie z którym realizowane są praktyki w szkołach, służące w założeniu budowaniu samoświadomości profesjonalnej, można określić jako „eksperymentowanie”. Realizacja ich celu, definiowanego w kategoriach ko-rozwoju (co-development), wymaga współpracy między przedstawicielami świata akademii i świata praktyki; studenci włączani w przezwyciężanie trudności czy rozwiązywanie problemów doświadczanych w szkolnej codzienności nie tyle (albo nie tylko) korzystają z doświadczeń nagromadzonych w miejscu praktykowania, ile wnoszą własne pomysły ich przezwyciężania powstające „pod okiem” facylitujących te procesy nauczycieli akademickich. Dominującą strategią edukacyjną jest tu facylitacja, czyli rodzaj odprawy „przed” zgromadzeniem doświadczeń praktycznych, „w ich trakcie” i „po” ich zakończeniu. Oczekiwany (i mierzony) 
rezultat jest definiowany jako świadomość istoty i zainicjowanie procesu uwzględniania doświadczeń praktycznych w konstruowaniu osobistej wiedzy dotyczącej nauczania.

Praktyczność przygotowywania się do nauczania wyraża się zatem w takiej restrukturyzacji uczenia się, aby oparte na „głębszych” zasadach programu, realizowane na wzajemnym nauczaniu i nastawione na metapoznanie prowadziło jednocześnie do dzielenia się wiedzą z otoczeniem. Stąd najczęściej stosowaną strategią jest studium projektowe. Grupa studencka występuje tu jako zróżnicowana wewnętrznie wspólnota, dystrybuująca „na zewnątrz” interesujące dla rozwoju praktyki szkolnej ekspertyzy profesjonalne.

Rola teorii polega głównie na wzmacnianiu myślenia studentów. David Guile wskazuje w tym aspekcie dwie zasady (czy też piętra) tego wzmacniania: 1) wspieranie praktycznego rozumowania pojawiającego się w trakcie prac projektowych oraz 2) krytyczne badanie implikacji pojawiających się $\mathrm{w}$ tych procesach uczenia się teorii (rzecz jasna małego zasięgu). Do ugruntowanych w wiedzy formalnej koncepcji, pojęć, typologii studenci sięgają $\mathrm{w}$ trakcie wieńczących studia projektowe próbach uogólnienia nabytej wiedzy i takiej identyfikacji wynikających z nich praktycznych implikacji, aby skorzystać z nich podczas kolejnych poszukiwań. Przestrzeganie drugiej z zasad - krytycznego badania implikacji dydaktycznych teorii - przekłada się na rozpoznawanie takich ich aspektów, które zdaje się, że mogłyby nie mieć końca zwłaszcza w sytuacjach pozbawionych bezpośredniego uczestnictwa autorów wypracowanej koncepcji, wyzwalać/ewokować rodzaj autorytarnych działań w klasie czy prowadzić niejako ,naturalnie” do obniżenia rangi konstruktywistycznego nauczania/uczenia się. Podważanie „oczywistości” aplikacyjnych wypracowanych koncepcji pracy edukacyjnej bowiem często prowadzi do wysuwania nowych wniosków, które ubrane w konwencje „,przemyślenia własnego myślenia" pogłębiają osobiste rozumienie (metapoznanie w znaczeniu samomonitorowania i samoregulacji) (Guile 2005a).

\section{Poznanie usytuowane w kontekście podstawą podejścia dialogiczno-partycypacyjnego}

Na drugim poniekąd biegunie definiowania relacji teorii i praktyki w edukacji do nauczania znajdują się koncepcje osadzone w antropologii kulturowej i/lub socjologii krytycznej. Przyjmujące niekiedy postać koniunkcji psychologii funkcjonalnej i pragmatyzmu, akcentują wagę edukacji w budowaniu wartości społeczno-demokratycznych. Teorie kulturowe, najczęściej przywoływane w edukacji nauczycieli, wiążą się z nazwiskami takich autorów, jak Barbara Rogoff, Etienne Wenger i Jane Lave czy Seth Chaiklin, a do najczęściej przywoływanych teorii należy koncepcja usytuowanego uczenia się (situated learning).

W programach kształcenia nauczycieli w komponencie profesjonalnym przyjęcie tego stanowiska teoretycznego oznacza: po pierwsze położenie szczególnego akcentu na kontekst i kulturowe podstawy praktyk szkolnych, po drugie przyjmowanie perspektywy holistycznej w patrzeniu na zjawiska edukacyjne, po trzecie skupienie w procesach ucze- 
nia się „w praktyce” i „poprzez praktykę” na różnych formach „,wiedzenia” (knowing) , a nie tylko na wiedzy rozumianej tradycyjnie jako system uznanych naukowo twierdzeń, i wreszcie po czwarte organizowanie procesów budowania kompetencji profesjonalnych w zgodzie z triadą: afordancje ${ }^{7}$ - miejsce pracy zawodowej - biografia.

Jeśli uczenie się to społeczna i kolaboratywna działalność, w której i dzięki której przygotowujący się do nauczania studenci mogą rozwijać swoje myślenie, to zgodnie ze wskazanymi wcześniej założeniami dba się o to, aby przybierało postać poznawczego terminowania/uczenia się rzemiosła (apprenticeship) we wspólnotach praktyki (communities of practices $)^{8}$. Grupowe uczenie się w terenie nie jest tu traktowane opcjonalnie jako alternatywa czy dopełnienie, ale jako sedno edukacji. Ponadto działania podejmowane ze studentami charakteryzuje nie tylko lokowanie ich w realnych praktykach występujących w różnych wspólnotach kulturowych, ale przenikające je nastawienie na przekraczanie dotychczasowych granic. Uczenie się uczenia jest postrzegane jako proces wzrostu w danej społeczności i stopniowego przesuwania się z uczestnictwa o charakterze peryferyjnym do centrum działalności (Lave, Wenger 1991). To osadzanie wspólnot uczenia się w społecznych praktykach, wykraczających poza terytorium instytucji edukacyjnych nie tylko uczelni, ale i szkół, jest czymś więcej niż integracją teorii i praktyki w rozumieniu typowym dla refleksyjnej praktyki. Wpisywanie uczenia się $\mathrm{w}$ autentyczną działalność kulturową, podejmowaną na zewnątrz instytucji, wyznacza zdecydowanie odmienny charakter definiowania interesującej nas tu relacji niż to, które zostało omówione wcześniej (odnośnie do podejścia monologicznego).

Wydaje się, że można tu mówić w jakimś sensie o generycznym modelu odbywania przez kandydatów na nauczycieli praktyk szkolnych w trakcie studiów. Nie chodzi tu jednak o zwykłe „dostrojenie” do środowiska przyszłej pracy i transfer zdobytych wiedzy i umiejętności. Nie jest tu mowa też tylko o wzmacnianiu praktycznego zaangażowania z użyciem narzędzi stosowanych np. w coachingu. Choć w ujęciu tym granice praktykowania są dość

6 Kategoria „wiedzenia” (nie znajduję w języku polskim lepiej brzmiącego thumaczenia), występująca też w koncepcji refleksyjnej praktyki Donalda Schöna, stosowana do uwyraźnienia szczególnej formy i charakteru wiedzy wbudowanej niejako w zajmowanie się praktyką, niekoniecznie uświadamianej i tym bardziej określanej.

7 Afordancje (affordances) - jak już wspomniałam - to występujące w środowisku możliwości działania. Istniejące obiektywnie i poddawalne pomiarom, choć nie zawsze i nie do końca rejestrowane (zauważane, uświadamiane), pozostające w określonej relacji, są zależne nie tylko od możliwości fizycznych jednostki, ale także od jej planów, przekonań i dotychczasowych doświadczeń (Norman 1999). Odnośnie do edukacji profesjonalnej oznacza to nastawienie na doświadczalne uczenie się (korzystanie) z tego wszystkiego, co mamy w zasięgu w realnym świecie praktyki zawodowej.

8 Wspomniane zakorzenienie w dyscyplinach innych niż psychologia niesie konsekwencje w języku. Oprócz przytaczanych terminów w dyskursie tym pojawiają się także takie terminy, jak: sprawczość (agency), wspólnota czy role pochodzące z teorii społecznej, a także terminy wspólne z kognitywizmem, np. rusztowanie (Chaiklin, Lave (eds.) 1996).

9 Określenia generyczny używam w znaczeniu spotykanym w informatyce jako możliwy do zastosowania $\mathrm{w}$ szerokim polu, przy akceptacji różnych typów argumentów, pracy z różnorakimi danymi albo w znaczeniu właściwy całemu „,rodzajowi” (zob. Słownik języka polskiego). 
płynne (praktyki są prowadzone zwykle w szerszym otoczeniu szkoły, a nie tylko w samej placówce), z pozycji uczelni procesy uczenia się są zarządzane (facylitowane) przez plany działania i spodziewane wyniki, a monitorowanie progresu bywa wspierane przez portfolio osiągnięć wraz z rodzajem briefingu i debriefingu (odprawa przed i omówienie po). Główną ramą edukacyjną jest tu bowiem biografia. Przepracowywanie doświadczeń jest wzmacniane analizami i interpretacjami gromadzonych materiałów, w tym zapisów refleksji osobistej (o charakterze introspekcji, towarzyszących podejmowanym działaniom i namysłowi nad wcześniejszymi spostrzeżeniami w formie refleksji nad refleksją), prowadzonych dzienników terenowych, a nawet pamiętników. Dominującą strategią są tu partycypacyjne czy partycypacyjno-krytyczne badania w działaniu. W literaturze polskojęzycznej znajdują się opisy tego typu praktyk edukacyjnych adresowanych do studentów krajowych (Lemańska-Lewandowska 2013; Ligus 2013; Wołodźko 2013; Szymczak 2015; Kruk 2018; Wiśniewska-Kin 2020), zagranicznych (Červinková 2013a; Mendel 2013), a w antologiach - teksty prac autorów reprezentujących amerykańską antropologię zaangażowaną i/lub etnografię edukacyjną zawierające przykłady pochodzące z codzienności edukacyjnej nauczycieli nauczycieli (zob. Červinková (red.) 2019).

Miejsce i rola teorii naukowej (wiedzy formalnej) podlegają kilku zasadom. Pierwszą $\mathrm{z}$ nich jest zasada formułowania refleksyjnego celu uczestnictwa we wspólnotach praktyk kulturowych. Na początku tej drogi mamy do czynienia z odwoływaniem się do pojęć teoretycznych. Ułatwiają one określanie powodów, dla których „zajmujemy się tym, czym się zajmujemy". Druga dotyczy uwzględniania zróżnicowanych form uogólnień w określaniu powiązań między uzasadnieniami a podejmowaną praktyką. Trzecia z kolei odnosi się do krytycznego badania autorytarnych pierwiastków wpisanych w uzasadnienia praktyk - rozpoznawanie i określanie autorytarnych aspektów praktyki obniżające w „naturalny” sposób ich wartość, prowadzące do opracowania kryteriów kwestionowania dawnych i rozwijania nowych praktyk. Każdy z tych procesów wymaga ponownego przemyślenia celu (uczestnictwa).

\section{Teorie działalności wraz z ko-konstruktywizmem społecznym, czyli podejście trialogiczne}

Podejście trialogiczne stanowi próbę wyjścia poza opozycję kognitywizm versus partycypacja. O ile bowiem cechą podejścia monologicznego jest koncentrowanie się głównie na sferze poznawczej kandydata na nauczyciela (indywidualnym konstruowaniu wiedzy), a cechą drugiego $\mathrm{z}$ podejść jest osadzenie uczenia się $\mathrm{w}$ dialogicznych procesach transformacji wspólnot praktyki, o tyle w podejściu trialogicznym akcentuje się zarówno indywidualne, jak i relacyjne oraz kontekstualne wymiary uczenia się. Przyjmowanie perspektywy konstruktywizmu społecznego (Wygotski i in.) rozwijanego dalej w oparciu o kulturowo-historyczną teorię działalności (Leontiew, Ilenkow, Dawidow), wzbogacanej o wpływy ze strony Bachtinowskiej semiotyki oraz koncepcji trzeciego poziomu uczenia się George'a Batsona, trafnie oddaje triada: kultura - dialog - działalność. 
Podejście to zasadza się na uznaniu fundamentalnej roli interakcji między osobami a kulturowymi narzędziami, zwanymi artefaktami w przestrzeni uczenia się i rozwoju ucznia/studenta/osoby dorosłej. Jak podkreślałam we wcześniejszych tekstach, przyjmuje się, że to, co zdarza się w mikrośrodowisku podmiotu uczącego się, warto obserwować w szerszym kontekście - przez pryzmat tego, co dzieje się w społeczności lokalnej i w świecie globalnym. Edukacja - z założenia - łagodząca napięcia między uniwersalnymi celami a zróżnicowaniem społeczno-kulturowym wymusza ugruntowywanie treści kształcenia w lokalnych warunkach wzrostu jednostki. W nauczaniu ujmowanym w kategoriach działalności kulturowej akcentuje się zróżnicowanie, dyskurs progresywny, kolektywną działalność. Stawanie się nauczycielem to nieustanne re-/de-/konstruowanie mikroprocesów kultury, których podmioty, a przede wszystkim każdy uczeń i nauczyciel definiują siebie (por. Gołębniak 2007).

Koncepcją reprezentującą trialogiczne podejście do edukacji nauczycieli, uwzględnianą w polskim piśmiennictwie, jest teoria rozszerzonego (ekspansywnego) uczenia się autorstwa Yrie Engeströma (Engeström, Sannino 2012). Wypracowana w obszarze pracy edukacyjnej z dorosłymi (Malewski 2010), odnoszona do pomocy udzielanej przez ekspertów/edukatorów grupom profesjonalistów doświadczających trudności w zajmowaniu się obiektem wpisanym w ich system działalności (Engeström, Sannino 2012), okazuje się aplikowalna również w kształceniu wstępnym nauczycieli (zob. np. Zamorska 2018; Gołębniak, Zamorska 2020).

Koncepcja ta stanowi rezultat autorskiego przepracowania źródłowych dla kulturowo-historycznej teorii działalności kategorii, takich jak: koncepcja strefy najbliższego rozwoju oraz zapośredniczania go przez narzędzia kulturowe Lwa Wygotskiego i jego współpracowników ${ }^{10}$, teorie działalności Aleksieja Leontiewa oraz dialektyka Jewgienija Iljenkowa odzwierciedlona w dydaktyce Wasilija Dawidowa ${ }^{11}$, a także antropologiczna koncepcja uczenia się na trzecim poziomie George’a Batesona ${ }^{12}$ oraz idea wielogłosowości Michaiła Bachtina ${ }^{13}$.

${ }^{10} \mathrm{Z}$ prac Lwa S. Wygotskiego za najbardziej znaczące dla konstruowania tego podejścia uznano - oprócz koncepcji strefy najbliższego rozwoju (przedefiniowanej tu ze względu na zajmowanie się uczeniem się i rozwojem na poziomie zbiorowości na strefę ekspansywnego przejścia z działań do działalności) - tezę zapośredniczania działania człowieka przez narzędzia i znaki kulturowe oraz interwencyjną metodologię podwójnej stymulacji (człowiek zmienia środowisko i zmienia też siebie).

${ }^{11}$ Wkład Aleksieja Leontiewa polega na przyjęciu w jego koncepcji teoretycznej różnicy między działaniem a działalnością, stanowiącej podstawę traktowania motywów i motywacji jako wpisanych w rozwój „treści rzeczywistych relacji życiowych osób uczących się” (Engeström, Sannino 2015: 217).

${ }^{12}$ Konceptualizacja poziomów uczenia się autorstwa brytyjskiego antropologa społecznego George'a Batesona, szczególnie pojęcie uczenia się na trzecim poziomie i związana z nim koncepcja „podwójnej pułapki”, traktowana jest przez autora z jednej strony jako rama teoretyczna, wzmacniająca koncepcję ekspansywnego uczenia się (zob. Engeström, Sannino 2012: 220).

${ }^{13}$ Uwzględnienie w koncepcji idei wielogłosowości oznacza dla autora konieczność brania pod uwagę na każdym etapie i poziomie ekspansywnego uczenia się i badań głosu pochodzącego z różnorodnych grup i warstw (nie tylko tych pochodzących ze świata akademii), co czyni rozwijane/animowane uczenie się „Z zasady procesem wielogłosowej debaty, negocjowania i organizacji” (Engeström, Sannino 2012: 220). 
W zrozumieniu istoty tego podejścia, skupionego na działalności wytwarzającej narzędzia (instrument-producing activity) (Engeström, Sannino 2012: 216), różniącego się od kształcenia tradycyjnego, gdzie mamy do czynienia w dużej mierze z działalnością polegającą na tworzeniu przedmiotu uczenia się (subject-producing activity) i tradycyjnie budowaną wiedzą, przyjmującą postać działalności wytwarzającej narzędzia (instrument-producing activity), pomaga zwrócenie uwagi na trzy przesłanki, a zarazem punkty wyjścia odnośnie do konstruowania ,programu” profesjonalnego uczenia się i rozwoju konstruowanego w oparciu o wymienione źródła. Pierwsza przesłanka akcentuje, że uczenie się to proces ukierunkowany nie tyle na przekazywanie i utrwalanie kultury, ile na jej tworzenie, nieustanne zmienianie. Druga to zachęta do tego, aby rozpatrywać je nie tyle w perspektywie wertykalnej, czyli osiągania przez jednostkę kolejnych, ujętych na odgórnie ustalonej skali, szczegółowych kompetencji profesjonalnych, ale patrzeć nań w perspektywie horyzontalnej, uwzględniającej ,ich ruch i wymianę” oraz krzyżowanie się różnych standardów funkcjonujących w zróżnicowanych kontekstach kulturowych. Trzecia z kolei sugeruje już wprost, że uczenie się w obszarze edukacji profesjonalnej, wspomagane wsparciem zgodnym z podejściem określanym jako CHAT (Cultural Historical Activity Theory), prowadzi do powstawania nowej wiedzy i koncepcji teoretycznych (Engeström, Sannino 2012).

Definiowane w ten sposób uczenie się Yrie Engeström sugeruje opatrywać metaforą rozszerzenia. Różni się ono bowiem pod względem jakościowym zarówno od uczenia określanego metaforą nabywania wiedzy, jak i uczestnictwa w społecznościach praktyki. Uczący uczą się czegoś, co jeszcze nie istnieje, co w języku CHAT-u oznacza tworzenie nowego obiektu stanowiącego podstawę podejmowania kolektywnej działalności. Inicjowane ukazaniem wewnętrznych sprzeczności w dotychczasowym systemie działalności, prowokuje przejście od działania do działalności. Analizy sprzeczności prowadzą bowiem do identyfikacji nowego celu i wypracowania nowego rozszerzonego obiektu i wzorca zorientowanej na niego działalności. W to ostatnie wpisane jest tworzenie teoretycznego pojęcia i nowego typu sprawstwa. Przechodzenie od abstrakcji do konkretu, zdaniem Yrie Engeströma, dokonuje się przez specyficzne, związane z uczeniem się działania poznawcze o charakterze spiralnym i zarazem cyklicznym. Pojedynczy (wzorcowy) cykl obejmuje zazwyczaj siedem faz, są to: 1) pytanie w znaczeniu czasownikowym, czyli kwestionowanie status quo; 2) analizowanie ,historii” radzenia sobie z problemem; 3) modelowanie nowego rozwiązania; 4) badanie/sprawdzanie nowego rozwiązania; 5) implementacja nowego modelu; 6) refleksja nad uruchomionymi procesami oraz 7) konsolidacja i generalizacja nowych praktyk (Engeström 1987).

Całość szkicowanego procesu określana jest mianem ,interwencji formatywnych”. I choć nie sposób nie zauważyć podobieństwa do opisywanego przez Kurta Lewina cyklu badań w działaniu, jednak zdaniem wielu przedstawicieli tego podejścia, nie tylko Engeströma, proponowana formuła tworzenia wiedzy przez poszukiwania jest z definicji bardziej szczegółowa niż sekwencje „,rozmrażania - przenoszenia - ponownego zamrażania” w modelu lewinowskim. Mamy tu czynienia z ,heurystycznym narzędziem koncep- 
cyjnym”, wywodzącym się z logiki przechodzenia od abstrakcji do konkretu. Każdorazowe wspieranie procesów uczenia się za pomocą tego modelu, stanowiąc swego rodzaju testowanie i krytykę, przyczynia się do wzbogacania leżących u jego podstaw założeń (Engeström, Sannino 2012: 225).

Koncepcja ta bywa najczęściej stosowana $\mathrm{w}$ ramach współpracy profesjonalnych badaczy z przedstawicielami szeroko rozumianego środowiska szkolnego w formule tymczasowych, organizowanych ad hoc wspólnot zajmujących się rozwiązywaniem „tu i teraz" lokalnej wersji jakiegoś palącego problemu praktyki oświatowej, w ramach laboratorium, pracowni czy studia uczenia się afiliowanym przy instytucji akademickiej. Najbardziej znane jest tu niewątpliwie pierwsze z nich, założone z inicjatywy Engeströma na początku lat 90. pod nazwą The Center for Research on Activity, Development and Learning (CRADLE) ${ }^{14}$. Podobne inicjatywy rozwijane są też w Polsce. Ewa Filipiak prowadzi Laboratorium Zmiany Edukacyjnej w Centrum Badań nad Uczeniem się i Rozwojem przy Uniwersytecie Kazimierza Wielkiego (zob. np. Filipiak 2019a, b; 2020), a Beata Zamorska - Laboratorium Rozwoju Profesjonalnego przy Dolnośląskiej Szkole Wyższej i Collegium Da Vinci (Zamorska 2018; Gołębniak, Zamorska 2020).

Praca edukacyjna ze studentami i nauczycielami, w ramach wiązania zajęć akademickich z praktykami szkolnymi czy też przygotowywania, indywidualnie bądź w małych zespołach, prac dyplomowych, oparta jest na współudziale w prowadzeniu interwencji formatywnych w miejscu pracy czy praktykowania. Uczenie się wynikające z odczucia i określenia dynamicznych napięć między składowymi (elementami) zastanych systemów działalności przybiera postać procesów przekraczania ich granic. Tworzona z udziałem studentów i nauczycieli akademickich społeczność uczenia się stanowi tu bowiem szczególny rodzaj systemu działalności zapośredniczanej przez narzędzia kulturowe i skupionej na celach/obiektach tej działalności. Mamy tu więc do czynienia z transformowaniem miejsc edukacji szkolnej przez współpracę w rozwiązywaniu nie tylko realnych, ale nade wszystko ,życiowych” (krytycznych) problemów wspólnot/społeczności przez włączanie ich do działalności i to z uwzględnieniem potencjału na zewnątrz szkoły.

Oczywiście tak definiowane ,praktykowanie” w szkole, które może być określane jako model konektywny, służące w wymiarze indywidualnym rozwijaniu refleksyjności, wzmacnianiu myślenia o rozwoju zarówno pod względem wertykalnym, jak i horyzontalnym, oparte na ,ścisłej współpracy” wiedzy formalnej i praktycznych umiejętności oraz zdolności do przekraczania granic i otwartości na zmiany, stałego rozwijania i resytuowania uczenia się, a także polikontekstualnych i łączących umiejętności, wymaga stałego rozwoju partnerstwa uczelni ze szkołami zainteresowanymi kreowaniem środowiska uczenia wszystkich podmiotów edukacji.

${ }^{14}$ Zob. teksty zamieszczone w czasopiśmie „Forum Oświatowe” autorstwa Mildy Brėdikyte (2012), współtwórczyni (z Pentiem Hakkarainem) Laboratorium Badań nad Zabawą przy Uniwersytecie w Wilnie, Ritvy Engeström (2014), wywodzącej się z CRADLE, Pentiego Hakkaraine'a (2015) w pracy zbiorowej pod redakcją Ewy Filipiak. Na marginesie warto podkreślić metaforyczne znaczenie tego akronimu (chat jako rozmowa w sieci i cradle w znaczeniu kolebki). 
Rolą teorii jest szeroki udział w rozpoznawaniu sprzeczności wpisanych w system działalności i wypracowanie nowych pojęć odnoszących się do ujawnionej sprzeczności (pojęcia teoretyczne służą do uzasadniania koniecznych zmian w systemie działalności). Do głównych zasad według Davida Guile’a należą zatem zasady: 1) określania powodów wprowadzania nowego pojęcia; 2) rozpoznawania zapośredniczanych związków między pojęciami teoretycznymi a nowo tworzonymi, służąca uzasadnianiu transformacji w systemie działalności; 3) krytycznego badania autorytarnych uzasadnień w systemie działalności, prowadząca do rozpoznawania autorytarnych i samoobniżających wartość aspektów systemu działalności poprzez takie rozwijanie kryteriów kwestionowania i transformowania tego systemu, co umożliwia przemyślenie „od nowa” sprzeczności, które są weń wpisane.

\section{Refleksja końcowa}

Odnosząc ten wywód do tytułowej tezy mojego artykułu, zamieszczonego w „Problemach Wczesnej Edukacji” w 2005 r. (Gołębniak 2005), wskazującej, że konstruktywizm rozumiany jako perspektywa poznawcza i dydaktyczna, obejmująca szeroki wachlarz teorii i koncepcji, stanowi fundament zmiany w kierunku czynienia uczenia się w szkole bardziej znaczącym nie tylko w odniesieniu do budowania metawiedzy, ale i wpisywania tychże procesów w transformację światów, w których te procesy zachodzą. Analiza porównawcza implikacji dydaktycznych głównych teorii stanowiących podstawę podejść najczęściej występujących w edukacji nauczycieli: monologicznego, opartego na kognitywizmie, partycypacyjnego, osadzonego na koncepcjach wiedzy sytuowanej w kontekście, czy trialogicznego, fundowanego na konstruktywizmie społecznym wraz z teorią działalności, dowodzi nie tyle możliwości budowania programów na ich pograniczach, choć jest to możliwe, a i w literaturze przedmiotu zakładane (Gardner (ed.) 2006), ile dość szerokiej przestrzeni dla podejmowania autorskich „projektów możliwości” w polu uczenia (się) kandydatów na nauczycieli konstruktywizmu w praktyce. Oczywiście w doborze szczegółowego podejścia decydującą rolę odgrywa zapewne przynależność do określonej szkoły myślenia teoretyczno-metodologicznego. Decydując się zatem na prace projektowe, badania partycypacyjne czy interwencje formatywne, warto zdawać sobie sprawę $\mathrm{z}$ różnic nie tylko w sposobach działania (i ich uzasadniania), ale także nade wszystko co do wpisanego w relację między teorią a praktyką rozumienia wiedzy (skupienie na nabywaniu w wypadku podejścia monologicznego, partycypacja uobecniona w podejściu dialogicznym czy wychodzeniu poza tę opozycję i wynikające z niej dalsze opozycje: obiekt vs podmiot; myślenie $v s$ działanie; nauczanie $v s$ uczenie się) w wypadku budowania programów na bazie konstruktywizmu społecznego Lwa Wygotskiego i teorii działalności. Z kolei pojawiać się może pokusa, aby odwołując się nie tyle albo nie tylko do teorii, ale i do praktyki, rozważyć możliwości typu synteza czy eklektyzm. O nieostrości granic świadczyć mogą choćby przesunięcia kognitywistów w stronę perspektyw kulturowych, 
o czym pisze m.in. ojciec psychologii poznawczej Ulrich Neisser (1999), czy dyskusje toczone w środowisku badaczy lokujących swe projekty w kulturowo-historycznej teorii działalności na temat zaliczania bądź nie interwencji formatywnych do action research (zob. np. Chaiklin 2011; Somekh, Nissen 2011). Oczywiście nie bez znaczenia jest także to, skąd i z czym, z jakimi bardziej czy mniej ukrytymi przekonaniami przychodzą do nas kandydaci na nauczycieli. Pytanie, czy to im należy oddać pole do negocjowania szczegółów decyzji co do paradygmatycznego osadzenia - na skali od purystycznej zgodności do eklektyzmu czy współgrania elementów trzech z wyróżnionych podejść w działaniu, pozostawiam otwarte. Ważne, aby „trzymając kurs” wyznaczony uznaniem społeczno-kulturowego wymiaru uczenia się jako główny, korzystać „tu i teraz” z możliwości, które w nauce o nauczaniu i nauczycielach tworzy już nie tylko przesunięcie kulturowe, ale i dyskursywne (zob. np. Edwards 2005; Gołębniak 2008). Być może, wskazane w niniejszym artykule tropy okażą się w tym względzie interesujące.

\section{Literatura}

Atroszko B. (2020), Miejsce innowacyjności w standardach ksztatcenia nauczycieli. „Forum Oświatowe", 1(63).

Brèdikytė M. (2012), Akt kulturowego upośredniania w zabawie dzieci. „Forum Oświatowe”, 2(47).

Červinková H. (2013a), Etnografia edukacyjna i badania $w$ działaniu: z warsztatu kształcenia nauczycieli. „Forum Oświatowe”, 1(48).

Červinková H. (2013b), Przywracając pamięć miastu. Z antropologiczno-pedagogicznych badań w działaniu. W: H. Červinková, B.D. Gołębniak (red.), Edukacyjne badania w działaniu. Warszawa, Scholar.

Červinková H. (red.) (2019), Antropologia i edukacja. Etnograficzne badania edukacyjne w tradycji amerykańskiej. Wrocław, Wydawnictwo Naukowe Dolnośląskiej Szkoły Wyższej.

Chaiklin S., Lave J. (eds.) (1996), Understanding Practice. Perspectives on activity and context. Cambridge, Cambridge University Press.

Chaiklin S. (2011), Social scientific research and societal practice: Action research in methodological light from Kurt Levin and Lev S. Vygotsky. „Mind, Culture and Activity”, 18(2).

Chomsky N. (1968), Language \& Mind. New York, Harcourt Brace Jovanovich, Inc.

Clark A. (2008), Supersizing the Mind: Embodiment, Action, and Cognitive Extension. Oxford, Oxford University Press.

Czerepaniak-Walczak M. (2014), Badania $w$ działaniu $w$ ksztatceniu $i$ doskonaleniu nauczycieli, „Przegląd Badań Edukacyjnych/ Educational Studies Review”, 2(19).

Czerepaniak-Walczak M. (2020), Jak zmienia się gramatyka edukacji? O przejawach i konsekwencjach (wymuszonej) iedukacji. „Forum Oświatowe”, 32(63).

Damásio A. (2011), Błąd Kartezjusza. Emocje, rozum i ludzki mózg. Warszawa, Wydawnictwo Rebis.

Dudzikowa M., Knasiecka-Falbierska K. (2013), Sprawcy i/lub ofiary działań pozornych w edukacji szkolnej. Kraków, Oficyna Wydawnicza „Impuls”.

Dudzikowa M., Jaskulska S. (2016), Twierdza. Szkoła w metaforze militarnej. Co w zamian. Warszawa, Wolters Kluwer. 
Dylak S. (2013), Architektura wiedzy w szkole. Warszawa, Difin.

Edwards A. (2005), Let's get beyond community and practice: the many meanings of learning by participating. „The Curriculum Journal”, 16(1).

Engeström R. (2014), Uczenie się w ujęciu teorii działalności. „Forum Oświatowe”, 2(52).

Engeström Y. (1987), Learning by expanding: An activity-theoretical approach to developmental research. Helsinki, Orienta-Konsultit.

Engeström Y., Sannino A. (2012), Badania nad ekspansywnym uczeniem się: założenia, wnioski i przyszłe wyzwania. „Forum Oświatowe”, 1(46).

Filipiak E. (2019a), Cultural-historical theory by Lev S. Vygotsky (CHAT): strategies of studies on children's learning and development. From theory to change in practice. „Forum Oświatowe", 2(60).

Filipiak E. (2019b), Sieci wspólpracy i samokształcenia nauczycieli - pozory zmiany czy przestrzeń możliwości rozwoju kultury szkoły i jej uczestników. „Kwartalnik Pedagogiczny”, 64(1).

Filipiak E. (2020), Connaître les croyances des enseignants pour changer leur compréhension de ce qui se passe en classe. L'exemple du Laboratoire de changement éducatif en Pologne. „Revue internationale d'éducation", 84.

Fodor J. (2011), Język myśli LOT 2. Warszawa, Wydawnictwo Naukowe PWN.

Gardner J. (ed.) (2006), Assessment and Learning. London-Thousand Oaks-New Delhi, SAGE Publications.

Gołębniak B.D. (2005), Konstruktywizm - moda, ,nowa religia” czy tylko/aż interesujaca perspektywa poznawcza i dydaktyczna. „Problemy Wczesnej Edukacji”, 1(1).

Gołębniak B.D. (2007), Poza ,nabywanie” i ,uczestnictwo”. Ku społeczno-kulturowej teorii edukacji nauczycieli. W: R. Kwiecińska, S. Kowal, M. Szymański (red.), Nauczyciel-TożsamośćRozwój. Kraków, Wydawnictwo Naukowe Akademii Pedagogicznej.

Gołębniak B.D. (2008), Wyjść poza scjentystyczne i personalistyczne myślenie o „uczeniu się uczenia”. W: E. Filipiak (red.), Rozwijanie zdolności uczenia się. Wybrane konteksty i problemy. Bydgoszcz, Wydawnictwo Uniwersytetu Kazimierza Wielkiego.

Gołębniak B.D. (2019), Proces kształcenia. W: Z. Kwieciński, B. Śliwerski (red.), Pedagogika. Podręcznik akademicki. Warszawa, Wydawnictwo Naukowe PWN.

Gołębniak B.D., Krzychała S. (2015), Akademickie kształcenie nauczycieli-raport z badań. „Rocznik Pedagogiczny", 38.

Gołębniak B.D., Zamorska B. (2013), Nowy profesjonalizm nauczycieli. Idee-praktyki-przestrzeń rozwoju. Wrocław, Wydawnictwo Naukowe Dolnośląskiej Szkoły Wyższej.

Gołębniak B.D., Zamorska B. (2020), Wyjść poza opis. Interwencje formatywne w edukacji dziecka. W: M. Magda-Adamowicz, E. Kowalska (red.), Dziecko i dzieciństwo w badaniach pedagogicznych. Torun, Wydawnictwo Adam Marszałek.

Guile D. (2005a), Beyond the metaphors of 'acquistion' and 'particiaption': towards the social theory of pedagogy, Sevilla, ISCAR [niepublikowane materiały kongresowe].

Guile D. (2005b), Knowledge, Mediation and Activity: A critique of the 'knowledge economy' thesis and its implications for a social theory of pedagogy. $\mathrm{PhD}$ Thesis, University of London Institute of Education, https://discovery.ucl.ac.uk/id/eprint/10006659/, 24.09.2020.

Hakkarainen P. (2015), Podejście kulturowo-historyczne do rozwoju samoregulacji u dzieci w zabawie i uczeniu się. W: E. Filipiak (red.), Nauczanie rozwijajace we wczesnej edukacji wedtug Lwa S. Wygotskiego. Od teorii do zmiany w praktyce. Bydgoszcz, Agencja Reklamowo-Wydawnicza ArtStudio. 
Hutchins E. (1995), How a Cockpit Remembers Its Speed. „Cognitive Science”, 19(3).

Klus-Stańska D. (2000), Konstruowanie wiedzy w szkole. Olsztyn, Wydawnictwo Uniwersytetu Warmińsko-Mazurskiego.

Klus-Stańska D. (2018), Paradygmaty dydaktyki. Myśleć teoria o praktyce. Warszawa, Wydawnictwo Naukowe PWN.

Klus-Stańska D., Nowicka M. (2019), Sensy i bezsensy edukacji wczesnoszkolnej. Gdańsk, Harmonia.

Kruk J. (2018), Pracownia wczesnej edukacji jako środowisko uczace się. „Problemy Wczesnej Edukacji”, 3(42).

Kwiatkowska H. (red.) (2013), Uczłowieczyć komunikację. Nauczyciel wobec ucznia w przestrzeni szkolnej. Kraków, Oficyna Wydawnicza „Impuls”.

Lakoff G., Johnson M. (2020), Metafory w naszym życiu. Warszawa, Aletheia.

Lave J., Wenger E. (1991), Situated learning. Legitimate peripheral participation. Cambridge, Cambridge University Press.

Legierska L. (2013), Uczeń niepetnosprawny w reformowanej przestrzeni szkoły ogólnodostępnej. O realnych efektach radosnej twórczości legislacyjnej. W: Z. Gajdzica (red.), Człowiek z niepetnosprawnościa w rezerwacie przestrzeni publicznej. Kraków, Oficyna Wydawnicza „Impuls”.

Lemańska-Lewandowska E. (2013), Zmiana, która może wyzwalać... Na marginesie pewnego projektu. W: H. Červinková, B.D. Gołębniak (red.), Edukacyjne badania w działaniu. Warszawa, Wydawnictwo Naukowe Scholar.

Ligus R. (2013), Tutoring uczestniczacy $w$ akademickim kształceniu nauczycieli jako badanie w działaniu. W: H. Červinková, B.D. Gołębniak (red.), Edukacyjne badania w działaniu. Warszawa, Wydawnictwo Naukowe Scholar.

Malewski M. (2010), Od nauczania do uczenia się. O paradygmatycznej zmianie $w$ andragogice. Wrocław, Wydawnictwo Naukowe Dolnośląskiej Szkoły Wyższej.

Mendel M. (2013), Edukacyjna podróż w biografii jako badanie w działaniu. W: H. Červinková, B.D. Gołębniak (red.), Edukacyjne badania $w$ działaniu. Warszawa, Wydawnictwo Naukowe Scholar.

Neisser U. (1967), Cognitive psychology. Englewood Cliffs, Prentice-Hall.

Neisser U. (1999), Systemy polimorficzne. Nowe podejście do teorii poznania. W: Z. Chlewiński (red.), Modele umystu. Warszawa, Wydawnictwo Naukowe PWN.

Norman D. (1999), Affordances, Coventions and Design. „Interactions”, 6(3).

Sadownik A. (2012), Na rozstajnych drogach. Studium etnopedagogiczne kontrastowych karier szkolnych młodzieży. Wrocław, Wydawnictwo Dolnośląskiej Szkoły Wyższej we Wrocławiu.

Searl U. (1967), Cognitive Psychology. New York, Appleton-Century-Crofts.

Searle J.R. (1967), Imiona własne. W: H. Reichenbach i in., Logika i język. Studia z semiotyki logicznej. Wybór J. Pelc. Warszawa: PWN.

Siemieniecki B. (2013), Pedagogika kognitywistyczna. Studium teoretyczne. Kraków, Oficyna Wydawnicza „Impuls”.

Somekh B., Nissen M. (2011), Cultural-historical activity and action research. „Mind, Culture and Society", 18(2).

Spitzer M. (2007), Jak uczy się mózg. Warszawa, Wydawnictwo Naukowe PWN.

Szymczak J. (2015), (Wspót)bycie/(wspót)stawanie się refleksyjnym nauczycielem i uczniem. Portfolio oraz feedback jako strategie działania ku refleksyjności. W: E. Filipak (red.), Nauczanie rozwijajace we wczesnej edukacji wedtug Lwa S. Wygotskiego. Od teorii do zmiany w praktyce. Bydgoszcz, Agencja Reklamowo-Wydawnicza ArtStudio. 
Tomasello M. (2002), Kulturowe źródta ludzkiego poznania. Warszawa, Państwowy Instytut Wydawniczy.

Tomasello M. (2015), Historia naturalna ludzkiego myślenia. Kraków, Copernicus Center Press.

Tomasello M., Kruger A.C., Ratner H.H. (1993), Cultural Learning. „Behavioral and Brain Science", 16(3), DOI: 10.1017/S0140525X0003123X, 24.09.2020.

Tusting K., Barton D. (2003), Models of adult learning: a literature review. London, Institute of Education.

Wiśniewska-Kin M. (2020), Doświadczanie kultury innowacji w edukacji językowej-przeciw rutynie w uprawianiu dydaktyki. „Forum Oświatowe”, 1(63).

Wołodźko E. (2013), Ku autonomii studiowania: procesy, znaczenia, konteksty, zmiana. Olsztyn, Wydawnictwo Uniwersytetu Warmińsko-Mazurskiego.

Zamorska B. (2013), Nauczyciel $w$ dyskursach i pomiędzy dyskursami potocznymi i naukowymi. W: B. Kutrowska, A. Pereświet-Sołtan (red.), Poprzez praktykę do profesjonalizmu. Przygotowanie do zawodu nauczyciela. Wrocław, Wydawnictwo Naukowe Dolnośląskiej Szkoły Wyższej.

Zamorska B. (2018), Interwencje formatywne $w$ i dla inkluzji. Podejście kulturowo-historycznej teorii działalności. W: B.D. Gołębniak, M. Pachowicz (red.), Ku inkluzji społeczno-kulturowej w szkole. Od pedagogiki klasy do pedagogiki włączającej. Poznań-Wrocław, Wydawnictwo Naukowe Dolnośląskiej Szkoły Wyższej.

Żylińska M. (2013), Neurodydaktyka. Nauczanie i uczenie się przyjazne mózgowi. Toruń, Wydawnictwo Naukowe Uniwersytetu Mikołaja Kopernika.

\section{Akty prawne}

Rozporządzenie Ministra Nauki i Szkolnictwa Wyższego z dnia 25 lipca 2019 r. w sprawie standardu kształcenia przygotowującego do wykonywania zawodu nauczyciela, Dz. U. z 2019 r., poz. 1450, ze zm., http://isap.sejm.gov.pl/isap.nsf/DocDetails.xsp?id=WDU20190001450, 31.11.2020. 